\title{
SYNTHESIS, CHARACTERIZATION, QUANTITATIVE STRUCTURE-ACTIVITY RELATIONSHIP, DOCKING, ANTIBACTERIAL ACTIVITY, AND BRINE SHRIMP LETHAL STUDIES ON L-PHENYLALANINE SCHIFF BASES
}

\author{
JAYAPRAKASH R ${ }^{1,2}$, SAROJ KUMAR SHA ${ }^{3}$, HEMALATHA $\mathbf{S}^{3}$, EASWARAMOORTHY $\mathbf{D}^{1 *}$ \\ ${ }^{1}$ Department of Chemistry, B. S. AbdurRahman University, Vandalur, Chennai, Tamil Nadu, India. ${ }^{2}$ Department of Chemistry, Jerusalem \\ College of Engineering, Pallikaranai, Chennai, Tamil Nadu, India. ${ }^{3}$ School of Life Sciences, B. S. Abdur Rahman University, Vandalur, \\ Chennai, Tamil Nadu, India. Email: easwar@bsauniv.ac.in
}

Received: 10 August 2016, Revised and Accepted: 05 September 2016

\begin{abstract}
Objective: Aim of this work is to synthesize and characterization of the hydroxyl group the hydroxyl group substituted L-phenylalanine Schiff bases to compare their predicted quantitative structure-activity relationship (QSAR) and molecular docking against Escherichia coli protein ZipA (1s1j) outcomes with the antibacterial activity and brine shrimp lethal assay (BSLA) results.
\end{abstract}

Methods: The Schiff bases of L-Phenylalanine were synthesized by the simple condensation reaction using methanol, water in 2:1 ratio at reflux and were characterized by spectral techniques. QSAR parameters of the Schiff bases were predicted using java-based online and offline tools. Molecular docking carried through online mcule server and CLC Drug Discovery Workbench 3. Antibacterial activity and toxicity studies were conducted using broth dilution and brine shrimp lethal assay methods, respectively.

Results: The Schiff bases fulfilled the QSAR drug-likeness parameters and showed the docking score between -6.8 and $-6.0 \mathrm{Kcal} / \mathrm{mol}$ which are higher than amoxilicillin and gentamicin like standard drugs. They also possess good inhibition for urinary tract infection causing $E$. coli bacteria, and minimum inhibitory concentrations (MIC) exists between 3.25 and $5.25 \mu \mathrm{g} / \mathrm{ml}$. The brine shrimp lethal concentration for $50 \%$ mortality [LC $_{50}$ ]) between 58.73 and $135.6 \mu \mathrm{g} / \mathrm{ml}$.

Conclusion: Para, meta and 2,4 hydroxyl substituted Schiff bases exhibited good inhibition against Gram-negative E. coli bacteria at low concentration and the MIC exists below the $\mathrm{LC}_{50}$ value. The Schiff base showed high drug score, high docking score, and low toxicity than other Schiff base. Docking score, high inhibition, low clogP, low MIC

Keywords: L-phenylalanine, Schiff base, Quantitative structure-activity relationship, Docking, Antibacterial, Lethal concentration for $50 \%$ mortality.

(C) 2016 The Authors. Published by Innovare Academic Sciences Pvt Ltd. This is an open access article under the CC BY license (http://creativecommons. org/licenses/by/4. 0/) DOI: http://dx.doi.org/10.22159/ajpcr.2016.v9s3.14664

\section{INTRODUCTION}

Development of new antibiotic drug with high resistivity and control over the disease-causing in medicine and agriculture field is a welldocumented problem [1]. It was found that the Schiff bases are the key intermediates for the synthesis of numerous bioactive medicinal compounds from the primary amine. medicinal activities so far. They possess antimalarial possess antimalarial [2], anticancer [3], antimicrobial [4,5], antioxidant [6], and analgesic [7] characters. The Schiff bases are used as a reactant for the preparation of a number of bioactive heterocyclic compounds such as benzoxazines, formazones, 2-azetidinones, and 4-thiazolidinones [8]. Apart from the various Schiff base molecules, recently amino acid Schiff bases and their metal complexes have received great attention owing to their biological importance [9]. The metal complexes of amino acid Schiff bases and their antimicrobial activities [10-19] were reported earlier. But the quantitative (QSAR) properties [20], docking, and toxicity assay of the different hydroxyl group substituted Schiff bases of the Schiff bases of L-phenylalanine were not reported in detail so far. Therefore, this research studied the QSAR parameters of the Schiff bases using offline and online tools such as Data-Warrior, tomcat, molsoft [21,22], and molinspiration $[21,22]$ to reduce the wastage of chemical and time. Similarly, this research used cell division protein ZipA (PDB id-1s1j) of Escherichia coli for the molecular docking instead of cell wall protein. ZipA is bitopic cytoplasmic membrane protein with a short periplasmic $\mathrm{N}$-terminal region of an E. coli [23]. Based on the literature survey, we derived five Schiff bases from L-phenylalanine using 2-hydroxy (1a), 3-methoxy, 2-hydroxy (1b), 4-hydroxy (1c), 3-hydroxy (1d), and 2,4-dihydroxy (1e) benzaldehydes in 2:1 ratio methanol, water solvent, and the compounds were characterized by Fourier transform infrared (FTIR), ${ }_{1}^{1} \mathrm{H}$-nuclear magnetic resonance (NMR), and ${ }^{13} \mathrm{C}$-NMR spectral studies. We also performed molecular docking to realize how various positions of substituted hydroxyl group in Schiff bases binding with cell division ZipA protein of E. coli and compared with standard antibiotics such as amoxicillin and gentamicin. Docking study of cell division ZipA protein was carried out using online mcule 1-click docking server instead of auto dock Vina software [24] and the poses with the negative docking scores were recorded for the submitted smiles notation. Docking poses were studied using the CLC drug designing workbench 3 tool. The Schiff bases were carried for experimental antibacterial activity against $E$. coli [25] pathogen and Brine Shrimp [26,27] toxicity study for the serially diluted solutions. Finally, the computational outcomes were compared with experimental results.

\section{METHODS}

L-phenylalanine, 2-hydroxy benzaldehyde, 3-methoxysalicylaldehyde, 4-hydroxy benzaldehyde, and 2, 4-dihydroxy benzaldehyde were purchased from Sigma-Aldrich, USA. 3-hydroxy benzaldehyde was purchased from HiMedia, Mumbai. The solvents and all other chemicals were purchased from SRL chemicals, India. Melting points were measured by an open capillary method using Sunsim electric melting point apparatus. The FTIR spectra of Schiff bases were obtained by Jasco-6300 FTIR spectrometer. ${ }^{1} \mathrm{H}-\mathrm{NMR}$ and ${ }^{13} \mathrm{C}-\mathrm{NMR}$ 
spectra were recorded using a Bruker NMR400 spectrometer in dimethyl sulfoxide (DMSO) solvent. The tools used for the virtual screening are Java based tools such as Data molinspiration are the Javabased virtual screening tools. Structures were drawn using ChemDraw software. Docking tools such as mcule 1-click docking and CLC drug discovery workbench 3 were used. Similarly, cell division protein ZipA, PDB id-1s1j, UniProt name-ZIPA_ECOLI, and resolution-2,180 were used for the docking study.

E. coli ATCC 8739 was obtained from Biomaterial Contributor Network, USA. The Artemia cyst eggs were purchased from Aquamarine (Guindy, Chennai, India) and sea water was collected at Besant Nagar beach, Chennai, India.

\section{EXPERIMENTAL}

General procedure for the synthesis of L-phenylalanine Schiff bases (compounds 1a-1e)

Schiff bases of L-phenylalanine were prepared using 2:1 methanol and water instead of ethanol [13] in $100 \mathrm{ml} \mathrm{R.B} \mathrm{flask.} 10 \mathrm{ml}$ of $0.001 \mathrm{~mol}$ hydroxyl group substituted aromatic aldehyde dissolved methanolic solution was added dropwise to $5 \mathrm{ml}$ of $0.001 \mathrm{~mol} \mathrm{~L}$-phenylalanine hot water solutions. Then, the reaction mixture was refluxed for $3 \mathrm{~h}$ and the R.B flask was covered with silver foil. The reaction was monitored by thin layer chromatography using 8.5:1:0.5 t-butanol, water, and acetic acid elution system. Then, the reaction mixture was cooled to room temperature. After $12 \mathrm{hrs}$, the solid formed was filtered off washed with hot methanol-water mixture. The solid Schiff base was recrystallized from $20 \mathrm{ml}$ of 1:1 methanol, water mixture and stored in a vacuum desiccator over anhydrous calcium chloride.

(S, E)-2-(2-hydroxybenzylideneamino) -3-phenylpropanoic acid (1a)

Light yellow solid; yield-72\%; mp- $163^{\circ} \mathrm{C}$ (Bushra et al. $160-162^{\circ} \mathrm{C}$ ); M.F: $\mathrm{C}_{16} \mathrm{H}_{15} \mathrm{NO}_{3}$; molecular weight (MW): 269.3; FTIR $\left(\mathrm{v}, \mathrm{cm}^{-1}\right)$ : $\mathrm{OH}(\mathrm{COOH})-3580-2420, \mathrm{OH}-3580-2420, \mathrm{CO}-1680, \mathrm{CH}=\mathrm{N}-1620,{ }^{1} \mathrm{H}$ NMR (500 MHz, DMSO-d $) \delta 13.3(\mathrm{~s}, 1 \mathrm{H}), 8.48(\mathrm{~s}, 1 \mathrm{H}), 7.89(\mathrm{~s}, 1 \mathrm{H}), 7.67-7.41$ (m, 4H), 7.41-7.23 (m, 2H), $7.09(\mathrm{dd}, \mathrm{J}=7.5,1.8 \mathrm{~Hz}, 1 \mathrm{H}), 6.97(\mathrm{td}$, $\mathrm{J}=7.5,1.9 \mathrm{~Hz}, 1 \mathrm{H}), 6.85-6.60(\mathrm{~m}, 1 \mathrm{H}), 4.35(\mathrm{~d}, \mathrm{~J}=11.1 \mathrm{~Hz}, 1 \mathrm{H}), 3.48$ $(\mathrm{t}, \mathrm{J}=11.8 \mathrm{~Hz}, 1 \mathrm{H}), 2.94(\mathrm{~d}, \mathrm{~J}=12.4 \mathrm{~Hz}, 1 \mathrm{H}) \cdot{ }^{13} \mathrm{C}$ NMR $(125 \mathrm{MHz}, \mathrm{DMSO})$ $\delta$ 172.61, 164.59, 154.87, 137.07, 132.71, 131.09, 128.96, 128.79, $127.51,127.00,125.4,123.59,119.54,116.99,76.16,40.03$.

\section{(S, E) -2-(2-hydroxy-3-methoxybenzylideneamino) -3-} phenylpropanoic acid (1b)

Orange solid; yield - $70 \%$; mp- $223^{\circ} \mathrm{C}$ (Laila et al. $220^{\circ} \mathrm{C}$ ); M.F: $\mathrm{C}_{17} \mathrm{H}_{17} \mathrm{NO}_{4}$ MW: 299.32; FTIR (v, cm-1): OH-3390, C=N-1620, COO-1576, ArCH-3120, COOH-1982; ${ }^{1} \mathrm{H}$ NMR (500 MHz, DMSO-d $\left.{ }_{6}\right) \delta 11.56(\mathrm{~s}, 1 \mathrm{H})$ $9.97(\mathrm{~s}, 1 \mathrm{H}), 7.97(\mathrm{~s}, 1 \mathrm{H}), 7.49(\mathrm{dt}, \mathrm{J}=14.7,7.0 \mathrm{~Hz}, 4 \mathrm{H}), 7.45-7.27$ $(\mathrm{m}, 1 \mathrm{H}), 6.89(\mathrm{dd}, \mathrm{J}=7.5,1.8 \mathrm{~Hz}, 1 \mathrm{H}), 6.64(\mathrm{t}, \mathrm{J}=7.5 \mathrm{~Hz}, 1 \mathrm{H}), 6.12-5.86$ $(\mathrm{m}, 1 \mathrm{H}), 4.54-4.39(\mathrm{~m}, 1 \mathrm{H}), 3.68(\mathrm{~s}, 3 \mathrm{H}), 3.23(\mathrm{t}, \mathrm{J}=11.8 \mathrm{~Hz}, 1 \mathrm{H})$ $3.12(\mathrm{~d}, \mathrm{~J}=12.3 \mathrm{~Hz}, 1 \mathrm{H}) ;{ }^{13} \mathrm{C}$ NMR (125 MHz, DMSO) $\delta 172.61,164.47$, $154.88,150.88,149.75,137.07,128.96,128.79,127.61,127.00,125.8$, $119.33,117.89,113.22,76.16,56.45,40.03$.

\section{(S, E)-2-(4-hydroxybenzylideneamino) -3-phenylpropanoic acid} (1c)

Light yellow solid; yield-72\%; mp-165-169 ${ }^{\circ}$; M.F: $\mathrm{C}_{16} \mathrm{H}_{15} \mathrm{NO}_{3}$; MW: 269.3; FTIR ( $\mathrm{v}, \mathrm{cm}^{-1}$ ): OH-3545, CO (COOH)-3470, Ar-CH-3071, $\mathrm{CH}=\mathrm{N}-1632, \mathrm{C}-0-1276 ;{ }^{1} \mathrm{H}$ NMR $\left(500 \mathrm{MHz}, \mathrm{DMSO}-\mathrm{d}_{6}\right) \delta 11.24(\mathrm{~s}, 1 \mathrm{H})$ $9.36(\mathrm{~s}, 1 \mathrm{H}), 7.80(\mathrm{~s}, 1 \mathrm{H}), 7.49(\mathrm{~d}, \mathrm{~J}=7.0 \mathrm{~Hz}, 2 \mathrm{H}), 7.42(\mathrm{t}, \mathrm{J}=7.4 \mathrm{~Hz}$ $2 \mathrm{H}), 7.38-7.20(\mathrm{~m}, 1 \mathrm{H}), 7.04(\mathrm{~d}, \mathrm{~J}=7.0 \mathrm{~Hz}, 2 \mathrm{H}), 6.85(\mathrm{~d}, \mathrm{~J}=7.5 \mathrm{~Hz}, 2 \mathrm{H})$ 4.90-4.74 (m, 1H), $3.32(\mathrm{t}, \mathrm{J}=11.9 \mathrm{~Hz}, 1 \mathrm{H}), 3.09(\mathrm{~d}, \mathrm{~J}=12.3 \mathrm{~Hz}, 1 \mathrm{H}) ;{ }^{13} \mathrm{C}$ NMR (125 MHz, DMSO) $\delta 172.73,159.23,153.81,137.07,131.11$, $128.96,128.79,128.27,127.00,114.12,76.16,40.03$.

(S, E)-2-(3-hydroxybenzylideneamino) -3-phenylpropanoic acid (1d)

Light yellow solid; yield-70\%; mp-168- $171^{\circ} \mathrm{C}$; M.F: $\mathrm{C}_{16} \mathrm{H}_{15} \mathrm{NO}_{3}$; $\mathrm{M}$ Wt: 269.3; FTIR (v, cm${ }^{-1}$ ): OH-3525, CO (COOH)-3430, Ar-CH-3071,
$\mathrm{CH}=\mathrm{N}-1625, \mathrm{C}-0-1276 ;{ }^{1} \mathrm{H}$ NMR (500 MHz, DMSO-d $) \delta 11.68(\mathrm{~s}, 1 \mathrm{H})$, $9.29(\mathrm{~s}, 1 \mathrm{H}), 8.41(\mathrm{~s}, 1 \mathrm{H}), 7.52(\mathrm{~d}, \mathrm{~J}=6.9 \mathrm{~Hz}, 2 \mathrm{H}), 7.36(\mathrm{t}, \mathrm{J}=7.4 \mathrm{~Hz}, 2 \mathrm{H})$, 7.32-7.14 (m, 2H), $7.04(\mathrm{dt}, \mathrm{J}=7.4,1.7 \mathrm{~Hz}, 1 \mathrm{H}), 6.79(\mathrm{~d}, \mathrm{~J}=7.2 \mathrm{~Hz}$ $1 \mathrm{H}), 6.57(\mathrm{~s}, 1 \mathrm{H}), 4.38(\mathrm{~d}, \mathrm{~J}=11.0 \mathrm{~Hz}, 1 \mathrm{H}), 3.51(\mathrm{t}, \mathrm{J}=11.7 \mathrm{~Hz}, 1 \mathrm{H})$, $2.94(\mathrm{~d}, \mathrm{~J}=12.4 \mathrm{~Hz}, 1 \mathrm{H}) ;{ }^{13} \mathrm{C}$ NMR $(125 \mathrm{MHz}$, DMSO) $\delta 172.73,159.78$, 157.44, 137.07, 134.63, 129.99, 128.96, 128.79, 128.61, 128.44, 127.00, $125.97,116.73,114.09,76.16,40.03$.

(S, E)-2-(2,4-dihydroxybenzylideneamino) -3-phenylpropanoic acid (1e)

Dull yellow solid; yield-75\%; mp-220 ${ }^{\circ}$; M. F: $\mathrm{C}_{16} \mathrm{H}_{15} \mathrm{NO}_{4} \mathrm{M}$. Wt: 285.29 ; FTIR (v, $\left.\mathrm{cm}^{-1}\right)$ : OH- 3600, $\mathrm{CO}(\mathrm{COOH})-3570, \mathrm{Ar}-\mathrm{CH}-3071, \mathrm{CH}=\mathrm{N}-1632$, C-0-1276; ${ }^{1} \mathrm{H}$ NMR (500 MHz, DMSO-d ${ }_{6}$ ) $\delta 14.72$ (s, 1H), 9.83 (s, 1H), $9.61(\mathrm{~s}, 1 \mathrm{H}), 8.05(\mathrm{~s}, 1 \mathrm{H}), 7.78(\mathrm{~d}, \mathrm{~J}=7.0 \mathrm{~Hz}, 2 \mathrm{H}), 7.43(\mathrm{t}, \mathrm{J}=7.4 \mathrm{~Hz}, 2 \mathrm{H})$, 7.39-7.18 (m, 1H), 7.05 (d, J = 7.5 Hz, 1H), 6.59 (dd, J = 7.5, $1.8 \mathrm{~Hz}, 1 \mathrm{H})$, $6.32(\mathrm{~d}, \mathrm{~J}=1.8 \mathrm{~Hz}, 1 \mathrm{H}), 4.88(\mathrm{~d}, \mathrm{~J}=8.7 \mathrm{~Hz}, 1 \mathrm{H}), 3.10-2.81(\mathrm{~m}, 2 \mathrm{H}) ;{ }^{13} \mathrm{C}$ NMR (125 MHz, DMSO) $\delta 172.61,164.16,162.50,154.87,137.07$, $132.66,128.96,128.79,128.55,128.11,127.00,119.48,110.78,103.26$, 76.16, 40.03 .

\section{QSAR properties of Schiff bases}

Computer-aided drug innovation methods have played a major role in the development of therapeutically essential small molecules for the past decades. QSAR properties were determined for a particular synthesized new molecule for biological studies, and these properties can identify the molecule, whether it can act as a drug or not for further research. Many of the potential drugs were failed to reach the clinic because of absorption, distribution, metabolism, excretion-Tox liability problems. Hence, the structure-based design is now fairly repetitive because the important properties like molecular formula, the number of hydrogen bond acceptors and donors, mol $\log \mathrm{P}$, mol logs, molecular weight, polar surface area, molecular volume, and comparative drug-likeness scores were calculated to avoid the wastage of biological materials. These QSAR properties were calculated using Molinspiration and Molsoft predicting tools. The activity of all molecules and standard drugs was thoroughly examined under four criteria of effective drug activity in the areas of nuclear receptor ligand activity, ion kinase inhibition activity, channel modulation, and G protein coupled receptors ligand activity. Similarly, the preliminary computational drug-likenesses of the molecules are calculated by the methodology established by offline Data-Warrior software and tomcat online software. The partition coefficient $(\log P)$ value of Schiff bases was predicted using ChemSketch and compared with molinspiration tool values. All the synthesized molecules were found to fulfill the solubility requirements $(\log P)$ and showed drug character in tomcat tool. On analyzing with Lipinski's rules of Five, compounds showed mi $\log \mathrm{P} \leq 5 ; \mathrm{n} \operatorname{rot} \mathrm{b} \leq 5$ (except $1 \mathrm{~b}$ ), $\mathrm{MW} \leq 500$, $n O H N H \leq 5, n O N \leq 10$ and all the synthesized Schiff bases satisfied the rules.

\section{Molecular docking}

Docking is the formation of non-covalent protein-ligand complexes in drug design. The specified structure of a protein and a ligand, the task is predicting the structure of the binder complex. A docking technique evaluates the forces involved in the protein-ligand recognition such as van der walls bonding through hydrogen, electrostatic and place of the legend appropriately in the active site [28]. After conducting an adequate literature review, E. coli cell division, ZipA protein was selected as the target for this study, which is not reported so for. The crystal structure of the above target was obtained from mcule 1-click docking server. Ligand structures were done by drawing the structures using ChemSketch and converted to word based smiles notation. Docking simulations were performed with simple and fast mcule 1-click docking server. By evaluating the affinity of the compounds, four different docking scores were shown by the software for $1 \mathrm{a}, 1 \mathrm{~b}$, $1 \mathrm{c}, 1 \mathrm{~d}$, and 1e. Docking study gave comparatively good affinity with the particular E. coli cell division target at the binding site of X-26.0168, Y-14.1613 and Z-3.9038. All mcule docking images were viewed by CLC drug designing work bench-3 software. 


\section{Antibacterial assay}

The Schiff bases were tested for their inhibitory character on the growth of $E$. coli, thus bacteria can achieve resistance to antibiotics through morphological and biochemical alterations [29]. The antimicrobial activity was tested by broth dilution method using serially diluted solutions of $25,12.5,6.25 \mu \mathrm{g} / \mathrm{ml}$, respectively. The presence of hydroxyl groups in the Schiff base ligand plays an important role for its antimicrobial activity [30], and likewise the presence of imine group which imports in exposing the mechanism of transformation reaction in biological systems [31]. The Schiff bases showed inhibition against the growth of E. coli under the identical experimental conditions. The increase in biological activity of the Schiff bases may be due to the effect of the chelation on the normal cell process. Furthermore, the method of action of the Schiff bases may involve the formation of a hydrogen bond through the imine nitrogen $(>\mathrm{C}=\mathrm{N})$ with the energetic interiors of cell constituents, resulting in interference with the normal cell process [32]. After incubation at $37^{\circ} \mathrm{C}$ for $24 \mathrm{hrs}$, the antibacterial activity of the Schiff bases was determined by measuring the inhibition of the zone diameter in $\mathrm{mm}$ scale and minimum inhibitory concentrations (MICs) in $\mu \mathrm{g} / \mathrm{ml}$ unit from the triplicated trials.

\section{Toxicity study by brine shrimp lethal assay (BSLA) test}

Brine shrimp larvae were hatched and toxicity study [33] was carried out for the 1a-e Schiff bases. $1 \mathrm{~g}$ of the Artemia cyst egg was added in 1 1 of sea water and kept under aeration. A 60 Watts tungsten lamp was focused on the beaker for $30 \mathrm{hrs}$. After the hatching process matured, nauplii were taken for toxicity study. Toxicity test was carried out for the serially diluted Schiff base solutions of 10, 50,100, 200, and $250 \mu \mathrm{g} / \mathrm{ml}$. Test samples were diluted in $0.5 \mathrm{ml}$ DMSO, and stirred well up to the clear solution. The solutions were made up to $100 \mathrm{ml}$ of sea water in a $100 \mathrm{ml}$ standard flask. Each trial was carried using $10 \mathrm{ml}$ of test solution with 10 numbers of freshly hatched nauplii. Test solutions were kept for $24 \mathrm{hrs}$ and it was focused by a 25 Watts tungsten lamp at room temperature. After $24 \mathrm{hrs}$, numbers of live nauplii were counted and percentage of mortality was tabulated. The same test triplicated for each concentration. From the data, regression graph is plotted between logarithmic values of concentrations and percentages of mortality. The synthesized schiff bases exposed exposed considerable cytotoxic activity against Brine Shrimp nauplii, and lethal concentration for 50\% mortality $\left(\mathrm{LC}_{50}\right)$ value of Schiff bases was calculated from the regression equations. DMSO was used as a negative control to validate the test method. Statistical evaluations were performed using Microsoft Excel, 2010.

\section{RESULTS AND DISCUSSION}

\section{Synthesis and characterization}

The designated compounds (1a-e) were synthesized by the addition of equimolar quantities of the hydroxyl group substituted five different aromatic aldehydes to L-phenylalanine in 2:1 methanol, water at reflux condition for $3 \mathrm{hrs}$ according to Scheme 1. The reaction system was covered with silver foil to avoid the amino acid oxidation, the impurity formation and to get Schiff bases with high purity. Water is used as a solvent to dissolve the unreacted amino acid. The Schiff bases 1a-1e were obtained in good yields (70-75\%) with purity after crystallization.

The FTIR spectra of compounds 1a-e have shown strong and broad absorption bands in the range of $3400-2945 \mathrm{~cm}^{-1}$ due to stretching vibration of the $-\mathrm{OH}$ group of the carboxylic acid and the phenolic groups. The characteristic peak of the $-\mathrm{NH}_{2}$ primary amine stretching and the vibration disappeared in the IR spectrum, and these compounds displayed at $1620-1632 \mathrm{~cm}^{-1}$ was due to the imine group $(-\mathrm{CH}=\mathrm{N}-)$ stretching vibration. Proton NMR spectrum of 1 a to $1 \mathrm{e}$ showed singlet chemical shift at 13.3 (Bushra et al.), 11.56 (Laila et al.), 11.24 (Laila et al.), 11.68 (Laila et al.), 14.72 (Bushra et al.) ppm for carboxylic group carbon and are the chemical shifts are in coincidence with the reported journal values. Imine group proton identified between $8.41 \mathrm{ppm}$ and 7.97 ppm (Bushra et al., Laila et al.). Similarly, carbon NMR showed the chemical shift at 172 ppm for carboxyl group and Imine, carbon showed carbon peak between 159 and 154 for 1 a to 1 e Schiff bases.

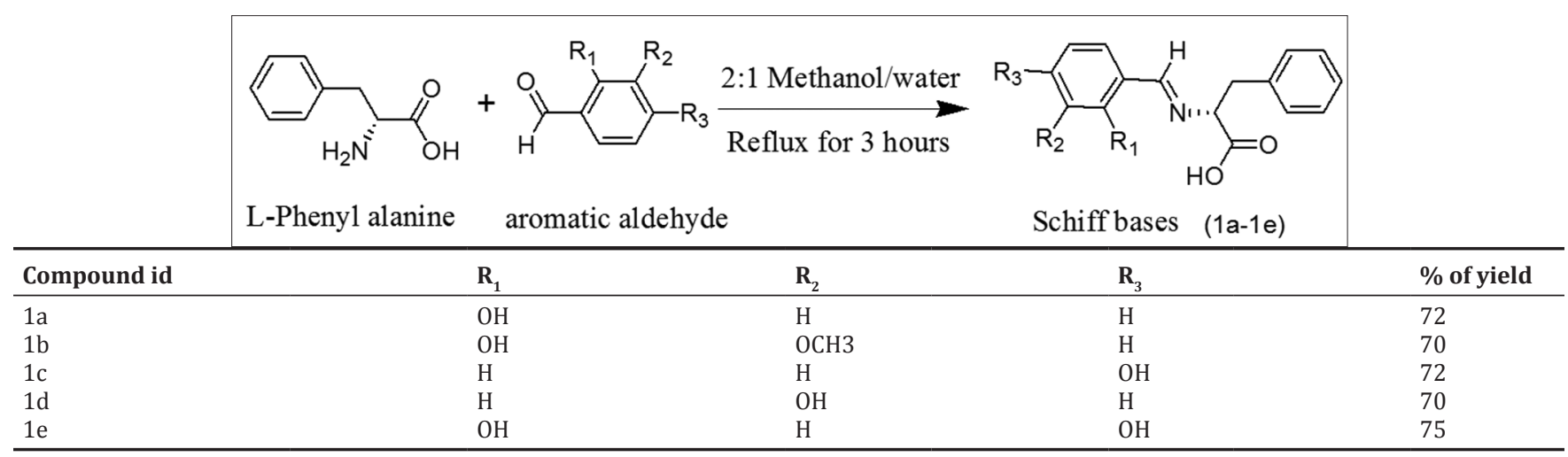

Scheme 1: Preparation procedure of L-phenylalanine Schiff bases 1a-1e

Table 1: Molinspiration predicted QSAR properties of Schiff bases 1a-e

\begin{tabular}{|c|c|c|c|c|c|}
\hline Properties & $1 \mathrm{a}$ & $1 b$ & 1c & 1d & $1 \mathrm{e}$ \\
\hline TPSA $^{\mathrm{a}}$ & 69.89 & 79.12 & 69.89 & 69.89 & 90.12 \\
\hline No atoms & 20 & 22 & 20 & 20 & 21 \\
\hline Molecular weight & 269.30 & 299.33 & 269.30 & 269.30 & 285.30 \\
\hline Number of $\mathrm{O}, \mathrm{N}$ atoms & 4 & 5 & 4 & 4 & 5 \\
\hline nOHNH & 2 & 2 & 2 & 2 & 3 \\
\hline Noumber of violations & 0 & 0 & 0 & 0 & 0 \\
\hline Number rotatable bonds & 5 & 6 & 5 & 5 & 5 \\
\hline GPCR $^{\mathrm{b}}$ ligand & -0.12 & -0.10 & -0.09 & -0.10 & -0.05 \\
\hline Ion channel modulater & -0.09 & -0.12 & 0.04 & 0.03 & -0.08 \\
\hline Kinase inhibitor & -0.44 & -0.37 & -0.40 & -0.42 & -0.35 \\
\hline Nuclear receptor ligand & -0.13 & -0.18 & -0.08 & -0.07 & -0.01 \\
\hline Protease inhibitor & -0.21 & -0.23 & -0.25 & -0.26 & -0.16 \\
\hline Enzyme inhibitor & 0.13 & 0.06 & 0.16 & 0.16 & 0.15 \\
\hline
\end{tabular}

${ }^{\mathrm{a} T o t a l}$ polar surface area, ${ }^{\mathrm{b}}$ Guanine nucleotide-binding protein-coupled receptor. QSAR: Quantitative structure-activity relationship 
Structures of the Schiff bases were characterized thoroughly and were carried for the preliminary QSAR properties prediction for druglikeness. We reviewed widely about the molecule based tools such as molecular descriptors and QSAR tools. Initially, the molecules were virtually screened through Molinspiration online tool and the predicted values are shown in Table 1 .

All the synthesized molecules were used for the partition coefficient prediction (clogP) using computational software such as Molinspiration, Molsoft, Chemsketch, Data-warrior, and pasilla Tomcat tools. The predicted $\operatorname{cog} \mathrm{P}$ and drug likeness values are shown in Table 2, and the result demonstrated the substituent effect on the Schiff bases. Data-warrior result showed the same drug score $(-0.9911)$ due to the standard 3000 molecules were referred for the prediction. However, molsoft showed different position effect because it used the maximum of 15,000 compounds for prediction. Similarly, clogP values are in decreasing order from $1 \mathrm{a}$ to $1 \mathrm{e}$. When compare the drug score of the starting materials such as 2-hydroxy benzaldehyde (-1.81), 2-hydroxy 3-methoxy benzaldehyde (-1.68), 3-hydroxy benzaldehyde $(-1.41)$ 4-hydroxy benzaldehyde (-1.44), 2, 4-dihydroxy benzaldehyde (-0.98), Schiff bases showed the enhanced drug score. Out of five compounds, $1 \mathrm{e}(-0.01)$ has shown higher and more resemblances to commercial drug. Our synthesized compounds were passed in pasilla tomcat drug-

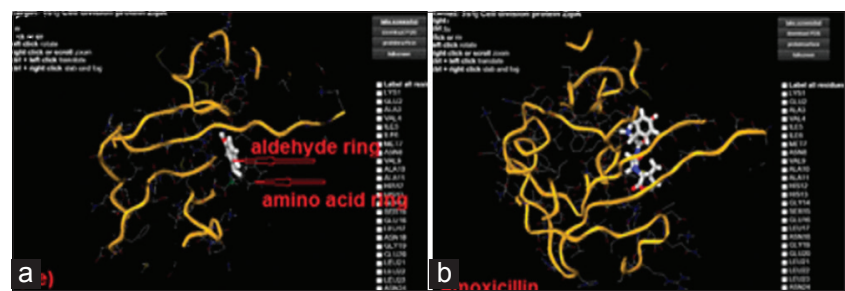

Fig. 1: Three-dimensional (3D) mcule docking images of Schiff bases and standard against protein $1 \mathrm{~s} 1 \mathrm{j}$. (a). 3D docking image of 1e, (b). 3D docking image of amoxicillin likeness test, and all the virtual screening tools were supported our Schiff bases.

Finally, computer aided, molecular docking was done for the Schiff bases and compared with standard antibiotics Amoxicillin and Gentamicin against cell division protein ZipA. It is observed that the Schiff bases showed more binding affinity than amoxicillin and shown in Table 3. New mechanism arrived from the docking study result that is molecules may also control the division of $E$. coli pathogen. The binding affinity of the chiral Schiff bases with the cell division protein are shown in Figs. 1 and 2.

All the synthesized Schiff bases are active against human disease causing pathogen E. coli at low concentrations and shown in Fig. 3. The serially diluted solutions and their inhibitions in $\mathrm{mm}$ are shown in Table 4. The result clearly showed that the antimicrobial character of the hydroxyl group substituted Schiff bases. Apart from the five Schiff bases, three Schiff bases 1c-e have shown the higher zone of inhibition than standard and the synthesized Schiff bases may have lower side effects than gentamicin due to the protected amine group. Schiff bases 1c-e showed the higher zone of inhibition for the various concentrations. $12.5 \mu \mathrm{g} / \mathrm{ml}$ concentrations of $1 \mathrm{a}-\mathrm{e}$ Schiff bases showed the zone of inhibition in the order of $8 \mathrm{~mm}, 5 \mathrm{~mm}, 13 \mathrm{~mm}, 13 \mathrm{~mm}$ and $15 \mathrm{~mm}$, respectively, which is shown in Fig. 3. The MIC of Schiff bases are exist from $3.25 \mu \mathrm{g} / \mathrm{ml}$ to $5.25 \mu \mathrm{g} / \mathrm{ml}$. 1e showed the higher zone of inhibition $(25 \mathrm{~mm})$ at low concentration $(3.25 \mu \mathrm{g} / \mathrm{ml})$.

After the preliminary trials against the pathogen, toxicity study has done on the Schiff bases by brine shrimp lethal assay method for the future study. Serially diluted solutions and their mortality percentages were calculated and shown in Table 5. It was correlated with the logarithmic values of concentrations by regression method. From the regression equation, $\mathrm{LC}_{50}$ was calculated for the Schiff bases and observed that the toxicity of the compounds decreased with increasing clogP values. 1c $1 \mathrm{~d}$-e Schiff bases showed higher $\mathrm{LC}_{50}$ (Table 5) value due to lower $\operatorname{clog} \mathrm{P}$ value. $\mathrm{LC}_{50}$ values of the Schiff bases 1a-e were displayed 58.73, 83.93,
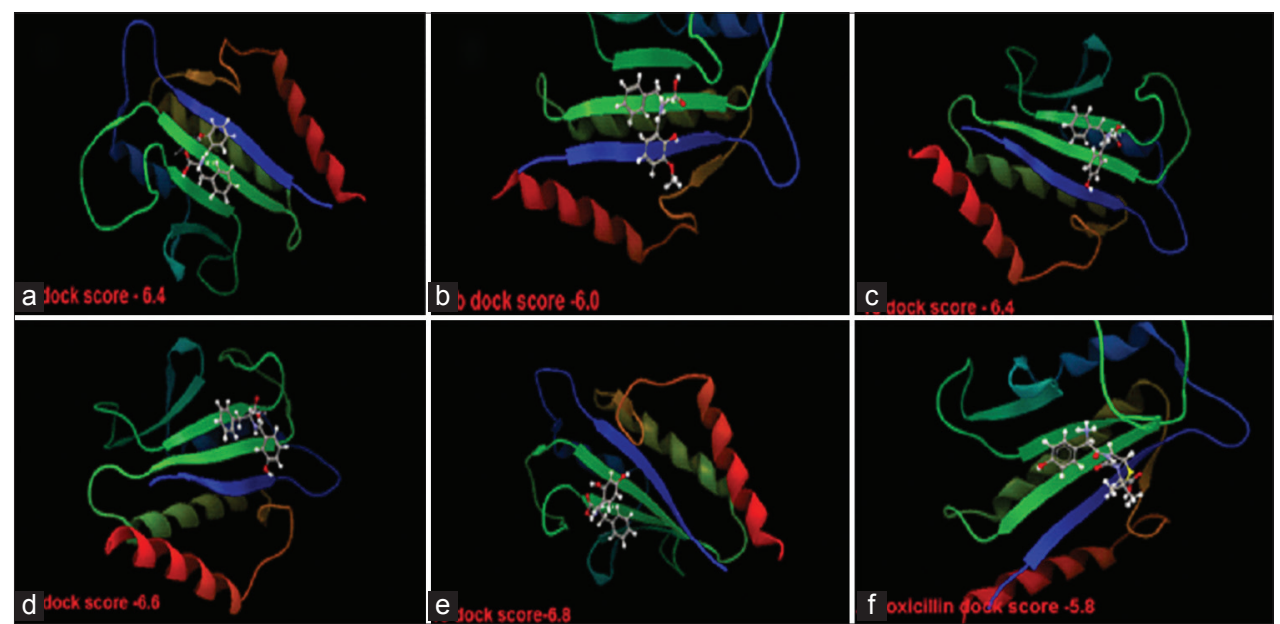

Fig. 2: Three-dimensional (3D) CLC work bench docking images with target protein 1s1j. (a). 3D docking image of 1a, (b). 3D docking image of 1b, (c). 3D docking image of 1c, (d). 3D docking image of 1d, (e). 3D docking image of 1e, (f). 3D docking image of amoxicillin

Table 2: Chemsketch, molinspire, data warrior, molsoft, tomcat tools predicted clogP and drug score of 1a-e

\begin{tabular}{|c|c|c|c|c|c|c|}
\hline \multirow{2}{*}{$\begin{array}{l}\text { Serial } \\
\text { number }\end{array}$} & \multirow[t]{2}{*}{ Compound ID } & \multicolumn{2}{|l|}{$c \log P$} & \multicolumn{3}{|c|}{ Drug score/drug-Likeness } \\
\hline & & Chemsketch & molinspiration & Data warrior & Molsoft & tomcat \\
\hline 1 & $1 \mathrm{a}$ & $3.46 \pm 0.43$ & 1.29 & -0.9911 & -0.57 & Drug \\
\hline 2 & $1 b$ & $3.24 \pm 0.41$ & 0.90 & -0.8817 & -0.39 & Drug \\
\hline 3 & $1 c$ & $3.33 \pm 0.45$ & 0.88 & -0.9911 & -0.43 & Drug \\
\hline 4 & $1 \mathrm{~d}$ & $3.28 \pm 0.44$ & 0.85 & -0.9911 & -0.48 & Drug \\
\hline 5 & $1 \mathrm{e}$ & $3.22 \pm 0.44$ & 0.79 & -0.9911 & -0.01 & Drug \\
\hline
\end{tabular}


Table 3: Mcule 1-click docking scores of 1a-e and antibiotics against cell division protein ZipA

\begin{tabular}{|c|c|c|c|c|c|c|}
\hline \multirow{2}{*}{$\begin{array}{l}\text { Serial } \\
\text { Number }\end{array}$} & \multirow[t]{2}{*}{ Substituent position in benzaldehyde (Shiff base) } & \multicolumn{4}{|c|}{ Docking scores in kcal/mol } & \multirow[t]{2}{*}{ Best score $\mathrm{kcal} / \mathrm{mol}$} \\
\hline & & 1 & 2 & 3 & 4 & \\
\hline 1 & 2-hydroxyl (1a) & -6.4 & -6.1 & -5.8 & -5.6 & -6.4 \\
\hline 3 & 4-hydroxy (1c) & -6.4 & -6.3 & -5.8 & -5.4 & -6.4 \\
\hline 4 & 3-hydroxy (1d) & -6.6 & -5.9 & -5.2 & -5.2 & -6.6 \\
\hline 5 & 2, 4-hydroxy (1e) & -6.8 & -6.3 & -5.8 & -5.6 & -6.8 \\
\hline 6 & Amoxicillin & -5.8 & -5.7 & -5.4 & -5.4 & -5.8 \\
\hline 7 & Gentamicin & -5.1 & -4.8 & -4.8 & -4.3 & -5.1 \\
\hline
\end{tabular}

Table 4: Diameter of inhibition zone (in mm)

\begin{tabular}{lllll}
\hline E. coli & & & & \\
\hline $\begin{array}{l}\text { Concentration } \\
(\boldsymbol{\mu g} / \mathbf{m l})\end{array}$ & $\mathbf{6 . 2 5}$ & $\mathbf{1 2 . 5}$ & $\mathbf{2 5}$ & MIC in $\boldsymbol{\mu g} / \mathbf{m} \mathbf{l}^{*}$ \\
\hline 1a (mm) & $5 \pm 0.2$ & $8 \pm 0.1$ & $13 \pm 00$ & $4.25 \pm 00$ \\
1b (mm) & $3 \pm 0.1$ & $5 \pm 0.2$ & $10 \pm 0.1$ & $5.25 \pm 00$ \\
1c (mm) & $8 \pm 0.1$ & $13 \pm 0.2$ & $21 \pm 0.2$ & $3.5 \pm 00$ \\
1d (mm) & $8 \pm 0.2$ & $13 \pm 0.2$ & $21 \pm 0.2$ & $4.2 \pm 00$ \\
1e (mm) & $10 \pm 00$ & $15 \pm 00$ & $25 \pm 0.1$ & $3.25 \pm 0.2$ \\
Control DMSO & - & - & - & - \\
Gentamicin (mm) & $7 \pm 00$ & $12 \pm 00$ & $15 \pm 0.1$ & - \\
\hline
\end{tabular}

*MIC: Minimum inhibitory concentration, DMSO: Dimethyl sulfoxide, E. coli: Escherichia coli

Table 5: Brine shrimp lethal assay and $\mathrm{LC}_{50}$

\begin{tabular}{|c|c|c|c|c|c|c|}
\hline \multirow{2}{*}{$\begin{array}{l}\text { Compound } \\
\text { ID(\%) }\end{array}$} & \multicolumn{5}{|c|}{ Concentrations in $\mu \mathrm{g} / \mathrm{ml}$} & \multirow{2}{*}{$\begin{array}{l}\mathrm{LC}_{50} \text { in } \\
\mu \mathrm{g} / \mathrm{ml}\end{array}$} \\
\hline & 10 & 50 & 100 & 200 & 250 & \\
\hline 1a of mortality & 0 & 26.6 & 56.6 & 80 & 100 & 58.73 \\
\hline $1 \mathrm{~b}$ of mortality & 0 & 33.33 & 46.66 & 70 & 86.66 & 83.93 \\
\hline 1c of mortality & 0 & 20 & 30 & 63.33 & 80 & 121.5 \\
\hline $1 \mathrm{~d}$ of mortality & 0 & 20 & 30 & 63.33 & 80 & 121.5 \\
\hline 1e of mortality & 0 & 10 & 26.66 & 63.33 & 80 & 135.6 \\
\hline
\end{tabular}

$\mathrm{LC}_{50}$ : Lethal concentration for $50 \%$ mortality

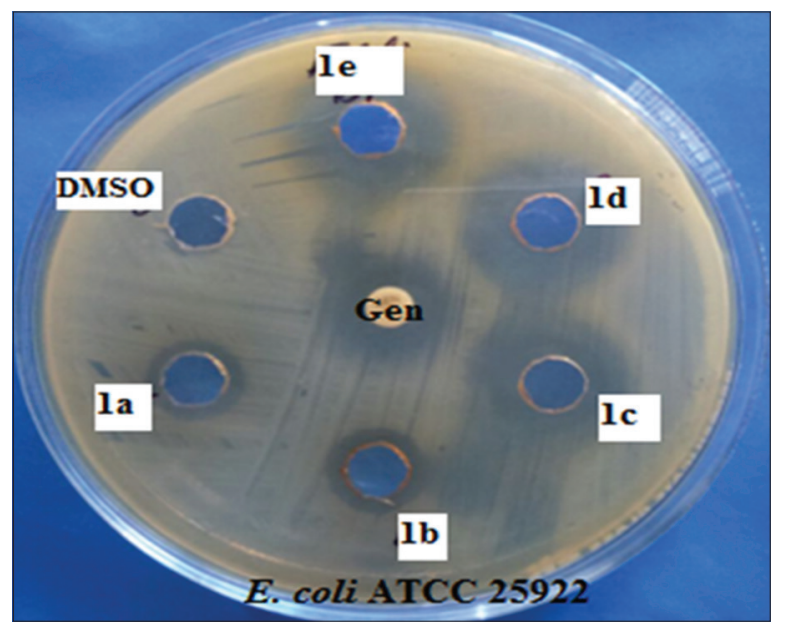

Fig. 3: Zone of inhibition against Escherichia coli at $12.5 \mu \mathrm{g} / \mathrm{ml}$

121.5, 121.5 , and $135.6 \mu \mathrm{g} / \mathrm{ml}$ after the triplicated trials. This result increasing order and predicted $\operatorname{cog} \mathrm{P}$ values are almost equal.

This research further revealed that the anti-bacterial MIC of Schiff bases were in increasing order from $1 \mathrm{e}<1 \mathrm{c}<1 \mathrm{~d}<1 \mathrm{a}<1 \mathrm{~b}$ and almost coincident with docking score and drug score. $\mathrm{LC}_{50}$ values are $1 \mathrm{e}<1 \mathrm{~d}<1 \mathrm{c}<1 \mathrm{~b}<1 \mathrm{a}$ are coincident with solubility partition coefficient slope, and all the
Schiff bases are fulfilling Lipinski rules of five. From the results and discussion, di hydroxyl group substituted 1e Schiff base showed stable result against the urinary tract infection causing $E$. coli and low toxicity.

\section{CONCLUSION}

The chiral Schiff bases (1a-e) were synthesized from the nutritional reputed analgesic and antidepressant supplement L-phenylalanine with hydroxyl group by the simple aqueous reaction. This research successfully completed the QSAR, docking, antibacterial, and toxicity study for the Schiff bases. Furthermore, this research confirmed that, the three (1c-e) Schiff bases showed enhanced antibacterial activity, particularly against human urinary tract infections causing bacterial strain E. coli when compared with gentamicin drug. QSAR parameters of our molecules satisfied with experimental results. Out of five Schiff bases, 1e showed excellent inhibition against the urinary tract infection causing E. coli, and further oral study will be carried for the efficacy in future.

\section{ACKNOWLEDGMENTS}

The authors are grateful to Jerusalem College of Engineering for providing the research facilities. Authors also thank Department of Chemistry, B.S.A.R University for providing analytical facilities (FTIR). The authors wish to thank Life Science Department, B.S.A.R University for biological activity screening. Author extend his gratitude to SRM University for the NMR facility.

\section{REFERENCES}

1. Tiwari S, Mujalda V, Sharma V, Saxena P, Shrivastava M, Synthesis and evaluation of Schiff's base of 4-quinazolinone analogues as antimicrobial agents. Asian J Pharm Clin Res 2012;5(1):98-100.

2. Li Y, Yang ZS, Zhang H, Cao BJ, Wang FD, Zhang Y, et al. Artemisinin derivatives bearing Munich base group synthesis and antimalarial activity. Bioorg Med Chem 2003;11:4363-7.

3. Desai SB, Desai PB, Desai KR. Synthesis of some Schiff base thiazolidinones and azetidinones derived from 2, 6 diaminobenzo [1, 2-d: 4, 5-d] bisthiazole and their anticancer activities. Heterocycl Commun 2001;7(1):83-90.

4. Panneerselvam P, Rather BA, Ravi Sankar Reddy D, Ramesh Kumar N. Synthesis and anti- microbial screening of some Schiff bases of 3-amino-6, 8- dibromo-2- phenyl quinazoline-4(3H)-ones. Eur J Med Chem 2009;44(5):2328-33.

5. Wadher SJ, Puranik MP, Karande NA, Yeole PG. Synthesis and biological evaluation of Schiff base of depsone and their derivative as antimicrobial agent. Int J Pharm Technol Res 2009;1(1):22-3.

6. Kumar PP, Rani BL. Synthesis and characterization of new Schiff bases containing pyridine moiety and their derivatives as antioxidant agents. J Chem Technol Res 2011;3:155-60.

7. Gupta JK, Biplab D, Saravanan VS, Correlation between the pKa and pharmacological properties of some imidazolin-5 $(4 \mathrm{H})$-ones, their precursors and Schiff's bases. Indian J Chem 2006;45B:2580-2.

8. Shah SN, Baseer MA. Synthesis and antimicrobial studies of some novel Schiff bases. Asian J Pharm Clin Res 2012;5(3):228-32.

9. Mahmoud WH, Mohamed GG, El-Dessouky MM. Synthesis, characterization and in vitro biological activity of mixed transition metal complexes of lornoxicam with 1, 10-phenanthroline. Int J Electrochem Sci, 2014;9:1415-38.

10. Al-Jeboori FH, Al-Shimiesawi TA, Oun MA, Abd-ul-Ridha A, 
Abdulla AY. Synthesis and characterization of amino acid (phenylalanine) Schiff bases and their metal complexes, J Chem Pharm Res 2014;6(8):44-53.

11. Al-Salami BK, Mohammed AH, Askar KA. Synthesis and characterization of new Schiff bases derived from 2-hydroxybenzaldehye and amino acids and their vanadyl complexes. Res J Pharm Biol Chem Sci 2014;5(4):1457-72.

12. Singh HL, Singh J. Synthesis, spectroscopic, molecular structure, and antibacterial studies of dibutyltin (IV) Schiff base complexes derived from phenylalanine, isoleucine, and glycine. Bioinorg. Chem Appl 2014;2014(716578):1-12.

13. Abdel Rahman LH, Abu-Dief AM, Hashem NA, Seleem AA. Recent advances in synthesis, characterization and biological activity of Nano sized Schiff base amino acid m (II) complexes. Int J Nano Chem 2015;1(2):79-95.

14. Amira AJ, Miaa AA. Schiff base complexes of Fe (III) derived from amino acids. Res J Chem Sci 2014;4(8):25-32.

15. Joseyphus RS, Shiju C, Joseph J, Dhanaraj CJ, Bright KC. Synthesis and characterization of Schiff base metal complexes derived from imidazole-2-carboxaldehyde with L-phenylalanine. Pharm Chem 2015;7(6):265-70.

16. Sakiyan I, Logoglu E, Arslan S, Sari N, Sakiyan N. Antimicrobial activities of n-(2-hydroxy-1-naphthalide-ne)-aminoacid (glycine,alanine,phenylalanine, histidine, tryptophane) Schiff bases and their manganese (III) complexes. Biometals 2004;17(2):115-20.

17. Neelakantan MA1, Rusalraj F, Dharmaraja J, Johnsonraja S, Jeyakumar T, Sankaranarayana Pillai M. Spectral characterization, cyclic voltammetry, morphology, biological activities and DNA cleaving studies of amino acid Schiff base metal(II) complexes. Spectrochim Acta A Mol Biomol Spectrosc 2008;71(4):1599-609.

18. Bennie RB, David ST, Joel C, Abraham SD, Seethalakshmi M, Pillai SI, Studies on binding affinities of phenylalanine based Schiff base metal complexes on bovine serum albumin, Pharm Chem 2014;6(5):343-52.

19. Jayaprakash R, Saroj KS, Hemalatha S, Easwaramoorthy D. QSAR, brine shrimp lethal assay and antimicrobial studies on synthesized 1-tryptophan-2,4-dihydroxy benzaldehyde. Int J Chem Technol Res 2016;9(6):48-54.

20. Bhagavathi. S, Prakash. A, Wadhwa.G. An insight to virtual ligand screening methods for structure-based drug design and methods to predict protein structure and function in lung cancer: Approaches and progress. J Crit Rev 2014;1(1): 10-24.

21. Dosanjh N, Sharma A, Bhardwaj SV, Randhawa V, Singh H. Insilco structure based drug designing of a potent inhibitor for human notchl - A therapeutic target for lymphoblastic leukemia. Int J Sci Nat 2011;2(4):705-12.

22. Lalitha P, Sivakamasundari S, Calculation of molecular lipophilicity and drug-likeness for few heterocycles Orient. J Chem 2010;26(1):135-41.

23. Pazos M, Natale P, Vicente M. A specific role for the ZipA protein in cell division: Stabilization of the FtsZ protein. J Biol Chem 2013;288(5):3219-26

24. Muthukala B, Sivakumari K, Ashok K. In silico docking of quercetin compound against the Hela cell line proteins. Int J Curr Pharm Res 2015;7(1):13-6

25. Al-Mudhafar MM. Synthesis, characterization and preliminary antimicrobial evaluation of new Schiff bases of ampicillin and amoxicillin derived from Isatin derivatives. Int $\mathrm{J}$ Pharm Pharm Sci 2016;8(5):113-6.

26. Rahman MH, Alam MB, Hossain MS, Jha MK, Islam A. Antioxidant, analgesic and toxic potentiality of methanolic extract of Stephania japonica (thunb.) miers. Leaf. Asian J Pharm Clin Res 2011;4(3):38-41.

27. Khor E, Wong N. Potential antioxidant and cytotoxic properties of secondary metabolite extracts from Carica papaya fruits and seeds. Int J Pharm Pharm Sci 2014;6(7):220-4.

28. Weber IT, Harrison RW, Kubinyi H, Folkers G, Martin YC. Molecular Mechanics Calculations on Protein-Ligand Complexes. Vol. 2. London Kluwer Academic Publishers; 1998. p. 115-27.

29. Cakir S, Bicer E, Odabas M, Albayrak C. Electrochemical and spectroscopic study of 4- (Phenyldiazenyl)-2-\{[tris- (hydroxymethyl) methyl] amino methylene $\}$ cyclohexa-3,5-dien-1(2H)-one: Mechanism of the Azo and imine electro-reduction. J Braz Chem Soc 2005;4:711-7.

30. Zidan AS. Mixed ligand complexes of nickel (II) dialkyldithiophosphates with 2- acetylpyridine semicarbazone and 2-acetylpyridine benzoylhydrazone. Phosphorus Sulfur Silicon Relat Elem 2003;178:567-82.

31. Sari N, Arslan S, Logoglu E, Sakiyan I, Antibacterial activities of some new aminoacid Schiff bases, GU J Sci 2003;16:283-88.

32. Dharmaraj N, Viswanathamurthi P, Natarajan K. Ruthenium (II) complexes containing bidentate Schiff bases and their antifungal activity. Trans Met Chem 2001;26:105-9.

33. Hoque N, Sohrab MH, Debnath T, Rana MS. Antioxidant, antibacterial and cytotoxic activities of various extracts of Thysanolaena maxima (roxb) Kuntze available in Chittagong hill tracts of Bangladesh. Int J Pharm Pharm Sci 2016;8(7):168-72. 